\title{
RELASI IMAN DAN ILMU PENGETAHUAN DALAM PERSPEKTIF AL-QURAN (Sebuah Kajian Tafsir Maudhui)
}

\author{
Ali Masrur \\ Dosen Fakultas Ushuluddin UIN Sunan Gunung Djati Bandung dan STFI Sadra \\ Komplek Citra AB 2 No. 6, Bumi Panyileukan Cipadung Kidul, \\ Kec. Panyileukan Ujung Berung Kota Bandung, Indonesia. \\ E-mail: alimasrur@yahoo.com
}

\begin{abstract}
This writing studies on relation between faith and science in the perspective of the Quran: a study of thematical interpretation. After studying Quranic verses on relation between faith and science using thematical method and unearthing interpretations from contemporary Quranic interpreters, such as Fazlur Rahman, Quraish Shihah, and Nurcholish Madjid, the result of this research are: Firstly, science is a tool to find a Qur'anic truth and God's truth itself. Science given by God to mankind as stock for mankind to be vicegerent of God in the earth. Therefore, science can not be separated with faith. By having science and faith, God will raise a standart of mankind, not only in this world, but also in the hereafter. Thus, the developing of science and technology has to be efforted to strengten faith of man to his God and to make man be nearer to his God. Secondly, confrontation between science and faith, did not caused by the teachings of the Qur'an, but because man has weeknesses: first, he has a carnal desire encouraging a man to fulfil his desire. In turn, it will be conflict of interest with another man. Second, narrowness of his reason. It means that human being emphasize short step (dunyā) more that long step (ăkhirah).
\end{abstract}

Keywords:

Faith; Science; Quran.

\begin{abstract}
Abstrak
Tulisan ini mengkaji relasi iman dan ilmu pengetahuan dalam perspektif Al-Qūran: Sebuah Kajian tafsir Maudhū'i. Setelah mengkaji ayat-ayat Al-Qur'ān tentang relasi iman dan ilmu pengetahuan dengan menggunakan metode maudhui dan menggali berbagai penafsiran dari para penafsir Al-Quran kontemporer, seperti Fazlur Rahman, Quraish Shihah, dan Nurcholish Madjid, dapat diperoleh beberapa kesimpulan di bawah ini: Pertama, Ilmu pengetahuan yang dimiliki manusia adalah sarana untuk menemukan kebenaran Al-Quran dan kebenaran Tuhan itu sendiri. Ilmu pengetahuan dalam perspektif Al-Qur'ān diberikan kepada manusia sebagai bekal manusia menjadi khalifah di muka bumi. Oleh karena itu, ilmu pengetahuan manusia tidak dapat dipisahkan dari keimanannya. Dengan ilmu pengetahuan dan iman yang dimilikinya, Allah akan mengangkat derajat manusia, tidak hanya di dunia, tetapi juga di akhirat. Pengembangan Dua hal tersebut mesti selalu diupayakan dalam rangka memperkuat keimanan kepada Allah dan semakin mendekatkan diri manusia kepada Allah Swt. Kedua, Pertentangan yang terjadi antara ilmu pengetahuan dan iman, bukan disebabkan oleh oleh ajaran Al-Quran, tetapi karena manusia memiliki beberapa kelemahan: pertama, memiliki hawa nafsu yang mendorong manusia ingin menuruti keinginannya yang menyebabkan konflik kepentingan dengan sesamanya b. Kesempitan pikiran, yakni manusia lebih mementingkan kepentingan jangak pendek dari pada kepentingan jangka panjang.
\end{abstract}

Kata Kunci:

Iman; Ilmu Pengetahuan; Al-Qur'an.

\section{A. PENDAHULUAN}

Dewasa ini, perkembangan ilmu pengetahuan begitu cepat sehingga seringkali mengganggu keimanan seorang mukmin. Pengembangan keimanan agama dan pengembangan ilmu pengetahuan dan teknologi ${ }^{1}$ seharusnya tidak saling bertabrakan satu sama lain. Pengembangan keimanan agama diharapkan tidak menghambat pengembangan ilmu pengetahuan dan teknologi sedangkan pengembangan ilmu

\footnotetext{
${ }^{1}$ Mengenai ilmu, filsafat, dan agama dapat dibaca Endang Saifuddin Anshari. Ilmu Filsafat dan Agama. Surabaya: PT Bina Ilmu, 1990.
} 
pengetahuan dan teknologi seharusnya juga tidak mengganggu pengembangan keimanan dan kehidupan beragama.

Sebagai contoh, terdapat polemik di surat kabar tentang tayangan televisi swasta yang dianggap tidak sesuai pada beberapa waktu yang lalu, yaitu mengenai nilai-nilai agama. Misalnya, penonjolan aurat wanita, cerita perselingkuhan dan sebagainya. Pihak yang berkeberatan dengan acara seperti itu mengatakan bahwa hal itu dapat merusak moral masyarakat. Namun, pihak yang tidak berkeratan dengan acara seperti itu mengatakan bahwa "kalau anda tidak suka dengan acara itu, matikan saja televisinya." Perusahaan televisi swasta tentu harus memikirkan keungtungan dengan selalu menayangkan film-film yang digemari oleh masyarakat pada umumnya. Jika masyarakat menyukasi film-film seks dan sadis, maka film semacam tentu memperoleh rating tinggi dan diminati oleh pemasang iklan. Kebijkan tersebut merupakan pemikiran sekuler yang memisahkan antara urusan bisnis dengan urusan agama. Tugas pengusaha adalah mencari keungtungan sebanyak-banyaknya, sedangkan tugas mendidik keimanan dan kehidupan beragama masyarakat adalah tugas guru agama, ustadz dan ulama.

Polemik semacam ini seharusnya dapat diberikan solusi dengan cara menerapkan sensor internal dari perusahaan televisi swasta sehingga keimanan dan kehidupan beragama masyarakat tidak terganggu.

Seperti konflik antara ajaran agama dan ajaran ilmu pengetahuan dengan cara menganggapnya "tidak ada atau sudah selesai" padahal ada dan belum diselesaikan. Sebagai contoh ialah teori mengenai asal usul manusia yang diajarkan di sekolah. Guru Biologi yang mengajarkan bahwa dalam sejarahnya, manusia itu berasal dari suatu jenis tertentu yang kemudian pecah.

\footnotetext{
${ }^{2}$ Arief Furchan. Peranan Agama dalam Pembangunan Iptek Nasional 1, 8. Diunduh pada tanggal 24 Januari 2013 dari http://www.pendidikan islam.net/index.php/makalah/41-makalah-tertulis/272peranan-agama-dalam-pembangunan-iptek.
}

menjadi dua bagian: bagian pertama mengikuti garis pongid yang menjadi kera modern, sedangkan bagian yang lain mengikuti garis manusia yang berkembang melalui proses revolusi dari manusia kera purba sampai ke manusia modern. Hal tersebut berbeda ketika Guru agama Islam mengajarkan bahwa, manusia itu diciptakan oleh Allah Swt, berdasarkan dalil-dalil naqli. (Lihat buku teks Biologi SMU untuk kelas tiga dan bandingkan denngan buku teks Pendidikan Agama Islam di SMU).

Ini adalah pertentangan teori klasik, antara teori evolusi dan teori penciptaan, yang pernah melanda Amerika Serikat beberapa tahun lalu. Hal tersebut masih berlangsung dalam dunia ilmu pengetahuan, sampai sekarang walaupun pendukung terhadap teori penciptaan ini jumlahnya semakin sedikit apabila dibandingkan dengan mereka yang mempercayai teori evolusi. Di bidang ilmu, konflik antara teori yang satu dengan yang lain adalah wajar dan merupakan rahmat karena konflik semacam inilah yang menimbulkan paradigma baru dalam ilmu pengetahuan dan menghasilkan teori-teori baru. Akan tetapi, jika konflik semacam ini diajarkan di sekolah tanpa diselesaikan maka kebingunganlah yang akan menjadi akibatnya. Seperti keputsan yang dilakukan oleh pendidikan Amerika, untuk menyelesaikan konflik ini dengan melarang diajarkannya teori penciptaan di seluruh negeri.

Berbeda halnya di Indonesia, konflik di sekolah ini tidak diselesaikan dan dianggap tidak ada. Pelajaran biologi hanya mengajarkan teori evolusi dalam bidang biologi. Hal tersebut kontras terlihat dalam buku, Pendidikan Agama Islam yang mengajarkan teori penciptaan dan menyalahkan teori evolusi tanpa menjelaskan letak kesalahan teori evolusi itu padahal, sampai saat ini, teori evolusi ini masih menjadi tulang punggung ilmu hayat (biologi). Secara teoritis, keadaan seperti ini akan menghasilkan lulusan SMU yang bingung mengenai asal usul manusia dan boleh jadi gurunya juga bingung. ${ }^{3}$

\footnotetext{
${ }^{3}$ Arief Furchan. Peranan Agama dalam Pembangunan Iptek Nasional 1; Mengenai dampak negatif ilmu pengetahuan dan teknologi, lebih lanjut dapat dibaca A.B. Shah,
} 
Setelah mengamati berbagai polemik dan konflik antara pengembangan keimanan keagamaan dan pengembangan iptek di atas, tentunya hal itu menimbulkan sebuah pertanyaan. Apa yang mesti dilakukan oleh para ulama di bidang ilmu agama maupun di bidang ilmu-ilmu umum. Bagaimana menyikapi pertentangan dan konflik semacam itu? Sebagai umat Islam kita memiliki sumbersumber ajaran Islam: Yakni Alquran, sunnah, Ijmā', dan Qiyās. ${ }^{4}$ Semua persoalan sudah seharusnya dikembalikan dan dicari jawabannya dari sumber-sumber pokok Islam tersebut, termasuk persoalan relasi antara keimanan dan kehidupan beragama, di satu sisi, dan pengmebangan ilmu pengetahuan dan teknologi, di sisi lain. Oleh karena itu, pertanyaan pokok bagi penelitian ini adalah bagaimana relasi Iman dan ilmu pengetahuan dalam perspektif Alquran? Mengapa terjadi pertentangan antara keduanya? Bagaimana solusinya ketika terjadi pertentangan antara keduanya menurut Alquran?

Setelah mengkaji dan mendiskusikan perkembangan ilmu pengetahuan dan teknologi yang seringkali menimbulkan polemik dan konflik dengan doktrin keimanan dan kehidupan beragama, dapat dirumuskan beberapa masalah yang merupakan fokus bagi penelitian ini. Masalah-masalah itu adalah:

1. Bagaimana pandangan Alquran tentang relasi iman dan ilmu pengetahuan.

2. Apakah iman dan ilmu pengetahuan itu sejalan atau bertentangan?

3. Menurut Alquran, apakah iman keagamaan mendukung pengembangan ilmu pengetahuan?

\footnotetext{
Metodologi Ilmu Pengetahuan (Jakarta: Yayasan Obor Indonesia, 1986), 7-9.

${ }^{4}$ Abdul Wahhab Khallaf, ,,Ilmu Ushul al-Fiqh (Tk.: Dar al-Rasyid, 2008), 21-69. Selain empat sumber di atas, Abdul Wahhab Khallaf juga menyebutkan beberapa sumber Islam yang lain, seperti istihsān, mashlahah mursalah, ,urf, ishtish $\underline{h a} b$, syar'u man

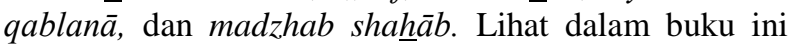
halaman 70-86. Mengenai dampak negatif ilmu pengetahuan dan teknologi, lebih lanjut dapat dibaca 79.
}

Jika terjadi pertentangan antara keduanya, apa sebab-sebab pertentangan antara keduanya menurut Alquran?

\section{B. LANDASAN TEORITIS}

\section{Tinjauan Pustaka}

Nurcholish Madjid dalam Islam Doktrin dan Peradaban menulis bahwa sikap orangorang muslim begitu positif terhadap berbagai budaya bangsa-bangsa lain. Oleh karena itu, peradaban Islam menjadi maju dan mampu menyatukan khazanah bersama secara internasional dan kosmopolit. Sebelum peradaban Islam, ilmu pengetahuan memang sudah ada, hanya saja ia bersifat nasionalistik dan parokialistik, dengan ketertutupan masing-masing dari pengaruh luar karena merasa paling benar. Nurcholish Madjid juga berpendapat bahwa umat Islam klasik menjadi pemimpin intelektual dunia sekurangkurangnya selama 4 abad, masa keemasannya pada zaman Khalifah Harun Al-Rasyid dan Al-Makmun, putranya, yang secara berurutan memerintah dari tahun 783 hingga 933. Di saat itu, barat (Eropa Kristen) masih dalam kegelapan mutlak, bahkan pada tahun 1000 masih sedemikian terbelakangnya dan mesti bersandar secara total terhadap ilmu pengetahuan dunia Islam.

Singkatnya, Umat Islam pada masa klasik benar-benar menjadi ummatan wasathan, umat penengah, dan umat yang maju, baik dari segi kebudayaan maupun peradabannya.

Quraish Shihab dalam Wawasan Alquran menyatakan bahwa teknologi dan hasilhasilnya di menjadi alat untuk mengingatkan manusia kepada Allah, serta mengingatkan bahwa manusia adalah khalifah yang kepadanya tunduk segala yang ada di alam raya ini.

Jika alat atau mesin dijadikan sebagai gambaran konkret teknologi, dapat dikatakan bahwa pada mulanya teknologi merupakan perpanjangan organ manusia. Lalu manusia menciptakan pisau sebagai alat pemotong, alat

\footnotetext{
${ }^{5}$ Nurcholish Madjid. Islam Doktrin dan Peradaban: Sebuah Telaah Kritis tentang Masalah Keimanan, Kemanusiaan, dan Kemoderenan, cet. ii. (Jakarta: Paramadina, 1992), 135, 143, dan 152.
} 
ini menjadi perpanjangan tangannya. Alat tersebut disesuaikan terhadap kebutuhan dan organ manusia. Alat itu sepenuhnya tunduk kepada pemakainya, melebihi tunduknya budak kepada tuannya. Kemudian teknologi berkembang, dengan memadukan sekian banyak alat sehingga menjadi mesin. Kereta, mesin giling, dan sebagainya, semuanya berkembang, khususnya ketika mesin tidak lagi menggunakan sumber energi manusia atau binatang, melainkan air, uap, api, angin, dan sebagainya. Pesawat udara, misalnya, adalah mesin. Kini, pesawat udara tidak lagi menjadi perpanjangan organ manusia, tetapi perluasan atau penciptaan organ baru manusia. Bukankah manusia tidak memiliki sayap yang memungkinkannya untuk terbang? Namun dengan pesawat, ia seperti memiliki sayap. Maka alat atau mesin tidak lagi menjadi budak, tetapi menjadi kawan manusia.

Dari hari ke hari tercipta mesin-mesin yang semakin canggih. Masin-mesin tersebut melalui daya akal manusia - digabunggabungkan dengan yang lainnya, yang membuat semakin kompleks, serta tidak bisa lagi dikendalikan oleh seorang saja. Tetapi akhirnya mesin dapat mengerjakan tugas yang dulu mesti dilakukan banyak orang. Pada tahap ini, mesin telah menjadi semacam "tandingan" manusia, atau lawan yang harus disiasati agar mau mengikuti kehendak manusia.

Dewasa ini telah lahit teknologi- khususnya dalam bidang rekayasa genetika-yang menumbulkan kekhawatiran menjadikan alat sebagai majikan, karena mampu menciptakan bakal-bakal "majikan" yang akan diperbudak dan ditundukkan oleh alat. Jika begitu, jelas ini bertentangan dengan kedua catatan yang disebutkan terdahulu.

Berdasarkan petunjuk Alquran, umat Islam dapat menerima hasil teknologi yang sumbernya netral, dan tidak menyebabakan maksiat, serta bermanfaat bagi manusia, baik yang mengenai unsur "debu tanah" manusia maupun unsur "ruh Ilahi" manusia

\footnotetext{
${ }^{6}$ M. Quraish Shihahb, Wawasan Al-Qur'an: Tafsir Maudhu'i atas Pelbagai Persoalan Umat, cet. iv. (Bandung, Mizan. 1996), 445-446.
}

Seandainya penggunaan dari teknologi melalaikan manusia dari dzikir dan tafakur, serta mengantarkannya kepada keruntuhan nilai-nilai kemanusiaan, maka pada saat itu, bukan hasil teknologinya yang mesti ditolak, melainkan kita harus memperingatkan dan mengarahkan manusia dalam menggunakan teknologi tersebut. Jika hasil teknologi dari semula dapat mengalihkan manusia dari jati diri dan tujuan penciptaannya, sejak awal tentu kehadirannya pasti ditolak oleh Islam, karena tidak sesuai fitrah mansuia yang mempunyai 'ruh' dan aqal. Maka tentunya perlu mengarahkan teknologi berjalan seiring dengan nilai-nilai Rabbani, atau dengan kata lain bagaimana memadukan pikir dan dzikir, ilmu dan iman? ${ }^{7}$

Rafael Raga Manan dalam Agama Iptek dan Masa Depan Kita menyatakan bahwa menguasai dan mengembangkan iptek modern yang canggih merupakan suatu tuntutan mendesak, yakni demi terwujudnya kemajuan dan kemakmuran. Namun kita harus tetap hati-hati dan bersikap waspada. Dalam perkembangan iptek modern yang canggih dapat menjadi suatu kekuatan otonom yang mampu menyingkirkan agama dari kehidupan masyarakat, seperti yang telah terjadi di dunia barat. Suatu masyarakat yang kehilangan agamanya, cepat atau lambat, akan menjadi masyarakat yang kehilangan jati dirinya.

Menurutnya, agama dan iptek memiliki hubungan yang komplementer. Agama memberi landasan moral bagi pengembangan iptek. Sementara iptek dapat memperjelas peranan agama yang hakiki. Oleh karena itu, agama dan iptek hendaknya saling terbuka. Hubungan yang demikian hendaknya dipertahankan jika kita ingin mewujudkan masyarakat Indonesia yang adil dan makmur berdasarkan Pancasila dan UUD 1945 karena agama dan iptek pada hakekatnya adalah ancilla vitae, abdi kehidupan.

${ }^{7}$ M. Quraish Shihahb, Wawasan Al-Qur'an: Tafsir Maudhu'i atas Pelbagai Persoalan Umat., 446. 


\section{Kerangka Teori}

Ada beberapa kemungkinan relasi antara iman keagamaan dan iptek: 1) berseberangan atau bertentangan, 2) bertentangan tetapi dapat beriringan secara damai, 3) satu sama lain tidak bertentangan, 4) Satu sama lain saling mendukung, agama sebagai dasar pengembangan iptek atau iptek mendasari penghayatan agama.

Pola hubungan pertama merupakan pola hubungan negatif, yag saling menolak satu sama lain. Apa yang dianggap benar oleh ilmu pengetahuan dan teknologi tidak dianggap benar oleh Agama. Pola hubungan seperti ini, pengembangan iptek akan menjauhkan seseorang dari keyakinan akan kebenaran agama dan pendalaman terhadap agama akan menjauhkan dari keyakinan terhadap kebenaran ilmu pengetahuan. Hal tersebut daoat dicontohkan pada zaman GalileioGalilei. Ketika berpendapat bahwa bumi mengitari matahari sedangkan gereja berpendapat bahwa matahari yang mengitari bumi, lalu Galileo dipersalahkan dan ia mendapatkan hukuman karena dianggap menyesatkan masyarakat.

Pola hubungan ke dua merupakan perkembangan dari pola hubungan pertama. ketika kebenaran iptek yang bertentangan dengan kebenaran agama tidak dapat disangkal, tetapi keyakinan akan kebenaran agama masih kuat di hati, jalan satu-satunya adalah menerima kebenaran keduanya dengan asumsi bahwa masing-masing mempunyai wilayah kebenaran yang berbeda. Kebenaran agama dipisahkan sama sekali dari kebenaran ilmu pengetahuan. Konflik antara agama dan ilmu, apabila terjadi diselesaikan dengan menganggapnya berada pada wilayah yang berbeda. Dalam pola hubungan seperti ini, pengembangan iptek tidak dikaitkan dengan penghayatan dan pengamalan agama seseorang karena keduanya berada pada wilayah yang berbeda. Pola hubungan seperti ini biasanya terjadi di masyarakat sekuler yang sudah terbiasa untuk memisahkan urusan agama dari urusan negara/masyarakat.

Pola ke tiga merupakan pola hubungan netral. Kebenaran ajaran agama tidak bertentangan atas kebenaran ilmu pengetahuan namun tidak saling mempengaruhi. Dalam masyarakat di mana pola hubungan seperti ini terjadi, penghayatan agama tidak mendorong orang untuk mengembangkan iptek dan pengembangan iptek tidak mendorong orang untuk mendalami dan menghayati ajaran agama. Hal dapat terjadi di masyarakat sekuler, karena masyarakatnya sudah terbiasa dengan pemisahan agama dann egara/ masyarakat, maka. ketika agama bersinggungan dengan ilmu, persinggungan itu tidak banyak mempunyai dampak karena tampak terasa aneh jika dikaitkan. Boleh jadi secara individu dampak itu ada, tetapi secara komunal pola hubungan ini cenderung tidak menimbulkan dampak apa-apa.

Pola hubungan yang ke empat adalah pola hubungan yang positif. Terjadinya pola hubungan seperti ini mensyaratkan tidak adanya pertentangan antara ajaran agama dan ilmu pengetahuan serta kehidupan masyarakat yang tidak sekuler. Secara teori, pola hubungan ini terjadi dalam tiga wujud: ajaran agama mendukung pengembangan iptek tetapi pengembangan iptek tidak mendukung ajaran agama, pengembangan iptek mendukung ajaran agama tetapi ajaran agama tidak mendukung pengembangan iptek, dan ajaran agama mendukung pengembangan iptek dan demikian pula sebaliknya.

\footnotetext{
${ }^{8}$ Rafael Raga Maran. "Agama Iptek dan Masa Depan Kita", dalam Buletin Ilmiah Tarumanagara Th. 9/ No. 31 (1994); 76.
}

\footnotetext{
${ }^{9}$ Arief Furchan. Peranan Agama dalam Pembangunan Iptek Nasional 1, 5-6.
} 
Dengan menggunakan empat kemungkinan tentang pola hubungan antara iman keagamaan dan ilmu pengetahuan sebagai kerangka teori, penelitian ini hendak mencari jawaban mengenai relasi keduanya dalam perspektif Alquran.

\section{METODE PENELITIAN}

Penelitian ini menggunakan metode tafsir maudhu'i untuk mengumpulkan dan menganalisa ayat-ayat Alquran yang berkaitan dengan relasi iman dan ilmu pengetahuan untuk mendapatkan satu gambaran yang utuh mengenai persoalan yang dikaji. Namun sebelumnya, penulis perlu menguraikan dua bentuk metode tafsir maudhu'i.

Penelitian ini adalah penelitian terhadap teks Alquran yang berbicara tentang relasi iman dan ilmu pengetahuan. Oleh karena itu, yang menjadi sumber utama dalam penelitian ini adalah Alquran itu sendiri yang kemudian diperkaya dengan penjelasan dari hadis nabi, penafsiran shahabat dan tabiin, dan penafsiran para mufassir Alquran, baik dari periode klasik, maupun periode abad pertengahan dan periode modern.

Penelitian ini adalah penelitian kepustakaan (library research). Oleh karena itu, jenis data yang digunakan adalah data-data kepustakaan, bukan data-data lapangan. Untuk mengkaji dan meneliti relasi iman dan ilmu pengetahuan dalam perspektif Al-Quran, diperlukan beberapa sumber yang relevan baik sumbersumber primer maupun sumber-sumber sekunder. Sumber primer adalah sumber utama untuk mengkaji persoalan yang akan diteliti. Dalam hal ini sumber primer yang akan digunakan adalah:

\section{Al-Quran Al-Karim.}

2. Kitab-kitab ilmu Al-Quran dan ilmu tafsir yang berhubungan dengan kajian asbabun nuzul, munasabah, makiyyah dan madaniyyah, nasikh mansukh dan lain-lain.

3. Kamus Al-Quran yang akan digunakan untuk mencari dan menghimpun ayat-ayat tentang relasi iman dan ilmu pengetahuan.

\footnotetext{
10 Arief Furchan. Peranan Agama dalam Pembangunan Iptek Nasional 1., 6.
}

4. Kitab-kitab tafsir Al-Quran baik yang klasik, abad tengah, maupun moderen untuk membantu memahami relasi iman dan ilmu pengetahuan. Untuk tafsir abad tengah akan digunakan kitab tafsir $A l$ Quran Al-,,Adzim karya Ibnu Katsir AlQurasyi Al-Dimasyqi (w. 774 H). Untuk tafsir moderen dan kontemporer akan digunakan beberapa karya berikut ini:

a) Fazlur Rahman, Major Themes of The Quran;

b) Quraisy Shihab, tafsir Al-Misbah, Wawasan Al-Quran: Tafsir Maudhu'i atas Pelbagai Persoalan Umat;

c) Tulisan Nurcholish Madjid tentang iman dan ilmu pengetahuan dalam Islam Doktrin dan Peradaban Sebuah Telaah Kritis tentang Masalah Keimanan,

Kemanusiaan, dan Kemoderenan.

Pengumpulan data dan analisa data dilakukan dengan menggunakan metode tafsir mawdhu'i yang telah digagas oleh Ahmad Sayyid al-Kumy dan kemudian dipertegas oleh „Abd al-Hayy al-Farmawi sebagai berikut:

1. Memilih atau menetapkan masalah penelitian Alquran yang akan dikaji secara maudhu'i (tematik)

2. Melacak dan menghimpun ayat-ayat yang berkaitan dengan masalah yang telah ditetapkan, apakah ia termasuk ayat Makkiyyah atau Madaniyyah.

3. Menyusun secara runtut ayat-ayat berdasarkan kronologi masa turunnya, disertai dengan pengetahuan mengenai latar belakang turunnya ayat (asbāb al-nuzūl)

4. Mencari korelasi (munāsabah) ayat-ayat tersebut di dalam masing-masing suratnya.

5. Tema bahasan disusun dengan kerangka yang tepat, sistematis, sempurna, dan utuh (outline).

6. Melengkapi pembahasan dan uraian dengan hadis-hadis, sebagai penyempurna dari bahasan

7. Menganalisa ayat-ayat tersebut secara tematik dan komprehensif dengan cara menghimpun ayat-ayat yang mengandung 
pengertian serupa, mengkompromikan antara pengertian yang ,am dan khash, antara yang muthlaq dan muqayyad, mengsinkronkan ayat-ayat yang secara lahiriah tampak kontradiktif satu sama lain, mendeskripsikan ayat nāsikh dan mansükh, sehingga semua ayat tersebut bertemu pada satu muara tanpa adanya perbedaan dan kontradiksi ataupun pemaksaan ayat terhadap sebagian ayat yang tidak tepat.

Inilah sesungguhnya yang dimaksud dengan metode mawdhu'i, sebuah metode tafsir yang baru di Fakultas Ushuluddin, yang sampai sekarang terus dikembangkan oleh para mufassir dan telah melahirkan banyak

karya yang mengagumkan. Dengan menggunakan metode tafsir mawdhu'i ini, penulis akan meneliti relasi iman dan ilmu pengetahuan dalam perspektif Alquran.

\section{HASIL DAN PEMBAHASAN}

\section{Makna Iman dan Ilmu Pengetahuan dalam Al-Qur'an}

Iman berasal dari kata amana yu'minu imanan yang artinya percaya. Secara istilah,sebagaimana terdapat dalam Al-Quran dan Hadis Nabi Saw., iman adalah percaya kepada Allah, malaikat-Nya, kitab-kitab-Nya, rasul-rasul-Nya, hari akhir, dan takdir-Nya. Iman itu sebenarnya melahirkan nilai-nilai yang berdasarkan Ketuhanan Yang Maha Esa (rabbaniyyah), yaitu tata nilai yang dijiwai oleh kesadaran bahwa hidup itu berasal dari Tuhan dan menuju kepada Tuhan (Inna lillahi wa inna ilayhi raji'un), "Sesungguhnya kita berasal dari Tuhan dan kita akan kembali kepada-Nya, maka Tuhan adalah "sangkan paran" dumadi, yakni asal dan tujuan hidup seluruh makhluk.

Sebagaimana pernah kita singgung sebelumnya, perkataan iman sering diartikan sebagai percaya. Pemberian arti demikian itu

${ }^{11}$ Abd Al-Hayy al-Farmawi, Metode Tafsir Mawdhu'i: Suatu Pengantar, terj. Suryan A. Jamrah (Jakarta: PT Raja Grafindo Persada, 1996), 45-46; Quraish Shihab, “Membumikan” Al-Qur'a: Fungsi dan Peran Wahyu dalam Kehidupan Masyarakat, cet. i. (Bandung, Mizan, 1992), 114-115. tidak salah, namun tidak mencakup secara keseluruhan maknanya. Untuk memperoleh gambaran maknanya secara lengkap, perlu kita ingat bahwa perkataan iman berasal dari akar kata yang sama dengan perkataan aman (Arab: aman, yakni kesejahteraan dan kesentausaan) dan "amanat" (Arab: Amanah, yakni keadaan bisa dipercaya atau diandalkan (Inggris: trustworthiness), lawan dari khianat).

Oleh sebab itu, kata "iman" selalu menunjukan rasa "aman" dan membuat orang mempunyai "amanat" itu tentu lebih daripada hanya "percaya", dalam arti sekedar percaya akan adanya Tuhan. (Dapat dicatat bahwa setan yang terkutuk pun percaya kepada Tuhan, bahkan iblis sempat "berdialog" dan "berargumentasi" langsung dengan Tuhan)." Karena pengertian iman sebagai "percaya" tanpa konsekwensi yang nyata bisa tak bermakna atau absurd, mungkin (mempercayai atau menaruh kepercayaan) kepada Tuhan akan sedikit lebih memperjelas makna iman. jika perkataan "mempercayai Tuhan" atau "menaruh kepercayaan" kepadaNya terkandung pengertian sikap ataupun pandangan hidup yang penuh kepasrahan, menyandarkan diri (tawakkal) kepada Tuhan dan kembali (ruju' atau inabah) kepada-Nya. Sebab, salah satu wujud rasa iman ialah sikap hidup yang memandang Tuhan sebagai tempat menyandarkan diri dan menggantungkan harapan. Oleh karena itu, konsistensi iman ialah (husnuzhzhan, berbaik sangka, yakni sikap optimis) kepada Tuhan, serta kemantapan kepadanya sebagai Yang Maha Kasih dan Maha Sayang, Ar-Rahman dan ArRahim). Justru rahmah (kerahmanan dan kerahiman), di samping pengetahuan (,,ilm), adalah sifat Tuhan yang paling komprehensif dan serba meliputi.

Iman adalah sikap seseorang yang sifatnya lebih mendalam dan tempatnya adalah di hati. Seperti terdapat dalam Surat Al-Hujurat ayat 14 di bawah ini,

\footnotetext{
${ }^{12}$ Nurcholish Madjid, Islam Doktrin dan Peradaban, 94-95.
} 


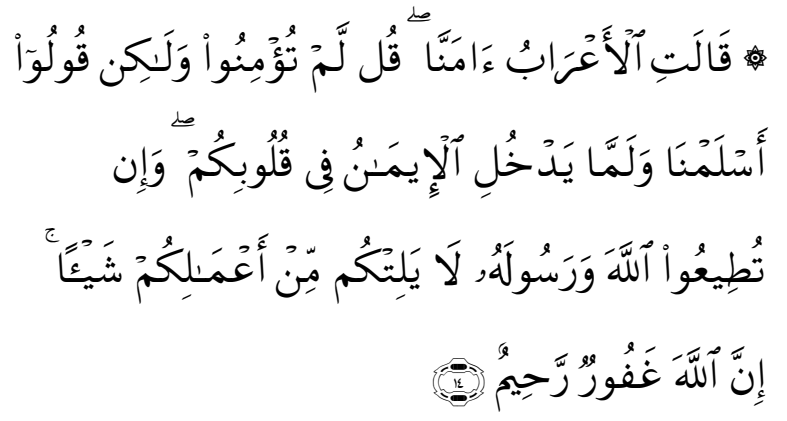

Orang-orang Arab dusun itu berkata: Kami beriman. Katakan:

Kamu belum beriman, tetapi katakanlah Kami telah tunduk (berislam). Keimanan itu belum masuk ke dalam hatimu. Dan kalau kamu mengikuti perintah Allah dan Rasul-Nya, maka tidak akan dikurangi nilai pekerjaan kamu sedikitpun. Sesungguhnya Allah itu Maha Pengampun dan Penyayang. (QS. AlHujurat (49): 14)

Nurchlish Madjid, ketika memahami ayatayat tentang iman, menyatakan bahwa Ketuhan Yang Maha Esa adalah inti semua agama yang benar. Setiap kelompok umat manusia telah mendapatkan ajaran mengenai Ketuhanan Yang Maha Esa melalu para rasul Tuhan. Karena itu, ada titik temu (kalimah sawa') antara semua agama

Manusia dan orang-orang muslim diperintahkan dan mengembangakn titik temu tersbut untuk dijadikan landasan hidup bersama. Tuhan adalah pencipta semua wujud yang lahir dan batin, dan Dia telah menciptakan manusai sebagai puncak ciptaan, untuk diangkat menjadi wakil (khalifah)-Nya di bumi. Oleh karena itu, manusia harus berbuat sesuatu yang dapat dipertanggungjawabkan di hadapan-Nya, baik di dunia maupun di akhirta. Orang muslim hendapknya berpandangan hidup bahwa, demi kesejahteraan dan keselamatan (salam, salamah) mereka sendiri di dunia maupun diakhirat.

\footnotetext{
${ }^{13}$ Nurcholish Madjid, Islam Doktrin dan Peradaban., $1-2$.
}

Dengan sikap yang mencerminkan kepasrahan kepada Tuhan Yang Maha Esa dan berbuat baik kepada sesama manusia.

atau kaum politeis. Dengan perkataan lain, problemnya ialah bagaimana mengubah manusia dari menganut paham Tuhan yang banyak kepada paham Ketuhanan Yang Maha Esa. Dalam kitab suci, memang disebutkan adanya suatu kelompok yang biasanya ditafsirkan sebagai kelompok penganut ateisme, tetapi dituturkan hanya sepintas saja, yang mengisyaratkan bahwa kelompok itu kecil sekali dalam masyarakat. Sebaliknya, kelompok yang paling banyak menantang nabi Saw. ialah kaum musyrikin.

Meskipun kasusnya terjadi di Mekkah dan sekitarnya, Hijaz khususnya dan Jazirah Arabiyah umumnya, sekitar 15 abad yang lalu, signifikansinya dapat digeneralisasikan meliputi seluruh umat manusia sejagad sampai sekarang, yaitu bahwa problem pokok umat manusia ialah politeisme. Sampai saat-saat terakhir, di zaman modern ini, pandangan dan sikap hidup politeistik tetap merupakan sumber masalah dan kesulitan umat manusia.

Ateisme, sebagai problema, memang cukup nyata. Namun dari pengamatan terhadap praktik orang-orang komunis abad ke-20 ini yang mencoba mengembangakan dan menerapkan ateisme secara ilmiah dan profesional, ternyata hasilnya justru lebih banyak berupa bentuk-bentuk politeisme yang sangat kasar dan dengan keras memenjarakan kemanusiaan. Hal ini bisa dilihat dari, misalnya, politeisme dalam bentuk pemujaan dan kultus kepada para pemimpin seperti Stalin, Mao, dan Kim. Bahkan dapat juga dikatakan bahwa komunisme telah tumbuh dan berkembang menjadi padanan agama (religion equevalent) dan para pemimpin komunis menjadi tandingan-tandingan Tuhan (God Equevalets, dalam bahasa Al-Qur'an, dinamakan andad). Bahkan berbagai tingkah laku orang komunis, seperti sikap penuh khidmat mereka ketika menyanyikan lagulagu tertentu atau membaca kutipan-kutipan karya seorang pemimpin, telah tumbuh dan berkembang menjadi semacam ibadah atau padanan ibadah. Mungkin di kalangan mereka, memang terdapat orang-orang ateis tulen, seperti adanya kaum dahriyyun di kalngan 
orang-orang Arab yang kebanyakan musyrik itu. Namun agaknya jelas, jumlah kaum ateis tulen itu kecil sekali.

Jika perhatikan secara seksama berbagai praktik politeistik yang ada, baik zaman dulu maupun yang modern, kita akan dapat mengerti mengapa politeisme atau syirik itu dalam kitab suci disebut sebagai dosa yang sangat besar, yang tak akan diampuni Tuhan. Yaitu karena praktek syirik tentu menghasilkan efek pemenjaraan harkat dan martabat manusia dan pemerosotannya. Ini berarti melawan natur atau fithrah manusia sendiri. Sebagai makhluk yang paling tinggi dan dimuliakan Tuhan. Sebab hakekat syirik, sama dengan mitos, adalah pengangkatan sesuatu selain Tuhan secara tidak benar, sedemikian rupa sehingga memiliki nilai lebih tinggi daripada nilai manusia sendiri. Dengan kata lain, orang yang melakukan syirik akan dengan sendirinya secar apriori menempatkan diri dan harkat serta martabatnya lebih rendah daripada obyek yang disyirikkan itu. Jika seseorang mensyirikkan suatu obyek atau gejala alam atau malah sesama manusia sendiri, dengan jalan menumbuhkan dan mengembangkan berbagai pandangan mitologis kepada obyek, gejala, atau manusia itu, orang itu secara apriori menempatkan dirinya di bawah kekuasaan obyek, gejala atau manusia yang disyirikkannya itu. Dalam keadaan yang berkelanjutan, orang itu dapat terjerumus ke dalam pola dan sikap hidup atas belas kasihan sesuatu yang dimitoskan itu. Inilah salah satu hakekat bahwa ia telah kehilangan harkat dan martabat kemanusiaannya yang tinggi. Ia tidak lagi mewujudkan pribadi manusia merdeka, dan ia dengan sendirinya menjadi budak atau hamba yang dimuliakannya.

Karena itu, demi harkat dan martabatnya sendiri, manusia harus menghambakan diri hanya kepada Tuhan Yang Maha Esa. Dalam gambaran grafisnya, manusia harus melihat ke atas, hanya kepada Tuhan Yang Maha Esa, Sang Pencipta, dan kepada alam harus melihat ke bawah. Sedangkan kepada sesamanya, manusia harus melihat secara mendatar atau

\footnotetext{
${ }^{14}$ Nurcholish Madjid, Islam Doktrin dan Peradaban., 95-96.

${ }^{15}$ Nurcholish Madjid, Islam Doktrin dan Peradaban., 96-97.
}

horizontal. Hanya dengan itu, manusia menemukan dirinya yang fithri dan alami sebagai makhluk dengan harkat dan martabat yang tinggi. Dengan kata lain, manusia menemukan kepribadiannya yang utuh dan integral hanya jika memusatkan orientasi transendental hidupnya kepada Allah, Tuhan Yang Maha Esa. Sebaliknya, bagi manusia, menempatkan diri secara harkat dan martabat di bawah sesamanya atau, apalagi, di bawah obyek dan gejala alam akan membuatnya berkepribadian tak utuh. Karena ia akan kehilangan kebebasannya dan hilangnya kebebasan itu, mengakibatkan pula hilangnya

kesempatan dan kemungkinan mengembangkan diri ke tingkat yang setinggitingginya.

Di sini, kita bertemu dengan makna iman lebih lanjut, yaitu menjadikan Tuhan Ynag Maha Esa sebagai satu-satunya (secara monoteistik, arah dan tujuan kegiatan hidup kita. Ungkapan sehari-hari bahwa kita berbuat sesuatu lillahi ta'ala dan demi ridha Tuhan menggambarkan adanya pengarahan tujuan hidup kepada-Nya. Menjadikan Tuhan sebagai tujuan hidup, dalam gambaran grafisnya, seperti diberikan oleh ajaran agama berarti menempuh hidup mengikuti jalan lurus, shirathal mustaqim, yang membentang antara dirinya sebagai das sein dan Tuhan sebagai das solen. Dalam realita kesehariannya, berarti manusia harus selalu berjuang untuk hidup sejalan dengan bisiskan suci hati nurani, bersifat cahaya, jadi suci dan baik. Dan hanya menghendaki kesucian dan kebikan.

Kata Ilmu dengan berbagai bentuknya disebutkan dalam Al-Qur'an sebanayak 854 kali. Kata ini dipakai dalam arti proses

pencapaian pengetahuan dan objek pengetahuan. ,Ilm dari segi bahasa berarti kejelasan. Oleh karena itu, segala yang terbentuk dari akar kata „Ilm memiliki ciri kejelasan. Misalnya, kata ,alam (bendera), „ulmat (bibir sumbing), „a'lam (gununggunung), ,alamat (alamat), dan lain sebagainya. Ilmu adalah pengetahuan yang jelas tentang sesuatu. Meskipun demikian,

\footnotetext{
${ }^{16}$ Nurcholish Madjid, Islam Doktrin dan Peradaban., 97-98.
} 
kata ,ilm berbeda dengan kata ,arafa (mengetahui), ,, arif (orang yang mengetahui), dan ma'rifah (pengetahuan).

Dalam Al-Quran, Allah Swt. tidak dinamakan ,,arif, tetapi ,alim yang memiliki kata kerja (Dia mengetahui). Biasanya AlQur'an menggunakan kata ini untuk Allah dalam hal-hal yang diketahuinya, walaupun gaib tersembunyi atrau dirahasiakan. Perhatikan objek-objek pengetahuan berikut ini yang dinisbatkan kepada Allah: ya'lamu ma yusirrun (Allah mengetahui apa yang mereka rahasiakan), ya'lamu ma fil arham (Allah mengetahui sesuatu yang berada di dalam rahim, ma tahmilu kullu untsa (apa

yang dikandung oleh setiap betina/perempuan), ma fi anfusikum (yang ada dalam dirimu), ma fis samawat wa ma fil ardhi (yang ada di langit dan di bumi), kha'inat ala'yun wa ma tukhfi al-shudur (kedipan mata dan yang disembunyikan dalam dada. Demikian juga kata ,ilm yang disandarkan kepada manusia. Semuanya mengandung makna kejelasan.

Dalam pandangan Al-Quran, ilmu adalah keistimewaan yang menjadikan manusia lebih unggul daripada makhluk-makhluk yang lain untuk menjalankan fungsi kekhalifahannya. Hal ini tercermin dari kisah kejadian manusia pertama yang dijelaskan oleh Al-Qur'an dalam surat Al-Baqarah (2): 31-32:

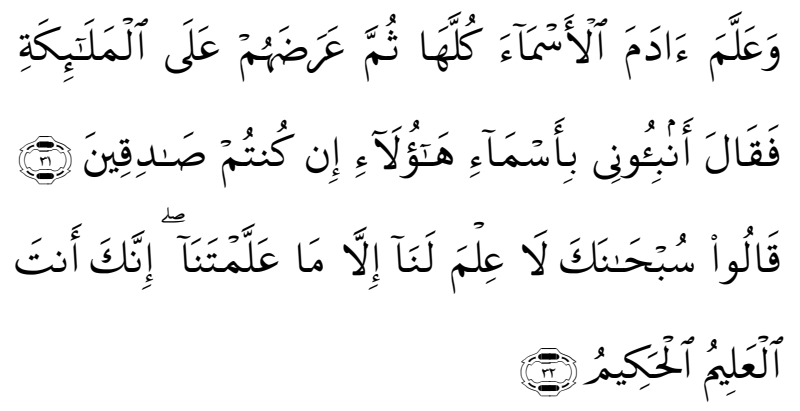

Dan Dia (Allah) mengajarkan kepada Adam, nama-nama (benda-benda) semuanya. Kemudian Dia mengemukakannya kepada para malaikat seraya berfirman, "Sebutkanlah kepada$\mathrm{Ku}$ nama-nama benda-benda itu jika kamu memang orang-orang yang benar. Mereka (para malaikat) menjawab, "Maha Suci Engkau, tiada pengetahuan kecuali yang telah Engaku ajarkan. Sesungguhnya Engaku Maha Mengetahui lagi Maha Bijaksana.

\footnotetext{
${ }^{17}$ M. Quraish Shihab, Wawasan Al-Qur'an, 434-435.
}

Manusia menurut Al-Qur'an, memiliki potensi untuk meraih ilmu dan mengembangkannya dengan izin Allah. Oleh sebab itu, banyak sekali ayat yang memerintahkan manusia untuk menempuh berbagai cara untuk mewujudkan hal itu. Berkali-kali juga Al-Qur'an menunjukkan betapa tinggi kedudukan orang-orang yang berilmu dan berpengetahuan.

Pandangan Al-Qur'an mengenai ilmu pengetahuan dapat diketahui prinsipprinsipnya setelah menganalisa wahyu pertama yang diterima oleh Nabi Muhammad Saw.

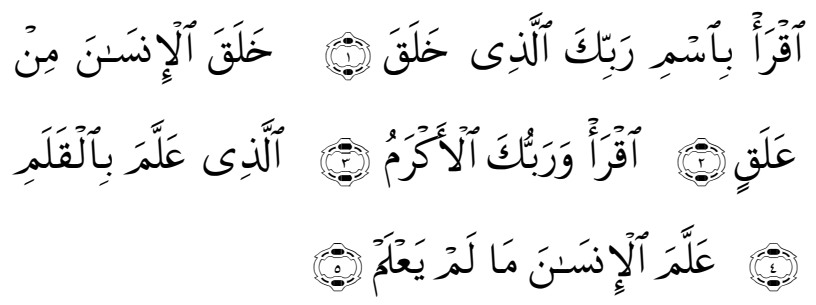

Bacalah dengan menyebut nama Tuhanmu yang menciptakan. Dia telah menciptakan manusia dari ,,alaq. Baalah, dan Tuhanmu Maha Pemurah. Yang mengajar manusia dengan pena, mengajar manusia apa yang tidak diketahuinya (QS Al-Alaq (96): 1-5).

Kata ,,iqra' diambil dari akar kata yang berarti menghimpun. Dari makna menghimpun lahirlah aneka makna seperti menyampaikan, menelaah mendalami, meneliti, mengetaui ciri sesuatu, dan membaca baik teks tertulis maupun tidak. Wahyu pertama itu tidak menjelaskan apa yang harus dibaca karena Al-Qur'an menginginkan umatnya membaca apa saja selama bacaan itu bismi rabbik, dalam arti atas nama Tuhan dan oleh karena itu, bermanfaat untuk kemanusiaan. Iqra' berarti bacalah, telitilah, dalamilah, ketahuilah ciri-ciri sesuatu: bacalah alam, tanda-tanda zaman, sejarah maupun diri sendiri, yang tertulis maupun yang tidak tertulis. Jadi, obyek dari perintah iqra' mencakup segala sesuatu yang dapat dijangkaunya.

Pengulangan perintah membaca dalam wahyu pertama itu bukan sekedar menunjukkan bahwa kecakapan membaca tidak akan diperoleh kecuali dengan mengulanmg-ulang bacaan atau membaca hendaknya dilakukan sampai mencapai batas maksimal kemmapuan. Namun hal itu untuk mengisyaratkan abhwa mengulang-ulang 
bacan bismi Rabbik ( atas nama Tuhanmu) akan menghasilkan pengetahuan dan wawasan baru, walaupun yang dibaca masih itu juga. Selain itu, dari wahyu pertama Al-Qur'an diperoleh isyarat bahwa ada dua cara perolehan dan pengembangan ilmu, yaitu Allah mengajar dengan pena yang telah diketahui oleh manusia lain sebelumnya, dan mengajar manusia dengan tanpa pena yang belum diketahuinya. Cara pertama adalah. Cara pertama adalah mengajar dengan peralatan atau atas dasar usaha manusia. Walaupun berbeda, keduanya berasal dari satu sumber yaitu Allah Swt.

Dalam perspektif Al-Qur'an, sebagaimana diisyaratkan oleh wahyu pertama, ilmu itu terdiri dari dua macam. Pertama, ilmu yang diperoleh, tanpa upaya manusia yang dinamakan ilmu ladunni, seperti disebut dalam Al-Qur'an surat Al-Kahfi (18): 65:

Lalu mereka (Musa dan muridnya) bertemu dengan seorang hamba dari hamba-hamba Kami yang telah kami anugerahkan kepadaNya rahmat dari sisi Kami dan telah Kami ajarkan kepadanya ilmu dari sisi Kami.

Kedua, ilmu yang diperoleh atas usaha manusia yang dinamakan ,ilmu kasbi. Ayatayat yang berbicara „,imu kasbi jauh lebih banyak daripada yang berbicara tentang ilmu ladunni. Pembagian ini disebabkan karena dalam andangan Al-Qur'an, ada hal-hal yang ada, tetapi tidak dapat diketahui melalui upaya manusia sendiri. Ada wujud yang tidak tampak seperti ditegaskan berkali-kali oleh AlQur'an, antara lain dalam firman-Nya,

$\mathrm{Aku}$ bersumpah dengan yang kamu lihat dan yang tidak kamu lihat (Al-Haqah (69): 38-39)

Oleh karena itu, obyek ilmu dalam perspektif Al-Qur' an meliputi materi dan nonmateri, fenomena dan nomena. Bahkan ada wujud yang tidak hanya tidak dapat dilihat, tetapi juga tidak dapat diketahui.

Secara tepat hukum kepastian Allah atau takdir-Nya itu. Maka ilmu pengetahuan yang benar akan dengan sendirinya bermanfaat untuk manusia.

\footnotetext{
${ }^{18}$ M. Quraish Shihab, Wawasan Al-Qur'an., 433-434.

${ }^{19}$ I M. Quraish Shihab, Wawasan Al-Qur'an., 436.
}

Ilmu pengetahuan atau science adalah prasyarat untuk mewujudkan salah satu tujuan diciptakannya alam raya ini, yaitu untuk manfaat manusia. Namun, ilmu pengetahuan itu diberikan oleh Allah kepada manusia melalui kegiatan manusia sendiri dalam upaya memahami alam raya ini. Hal ini berbeda dengan agama yang diberikan dalam bentuk pengajaran atau wahyu lewat para utusan Allah. Perbedaan itu disebabkan oleh perbedaan obyeknya: apa yang harus dipahami manusia melalui ilmu pengetahuan ialah halhal lahiriah dengan segala variasnya, termasuk yang tampak seperti gaib, misalnya, medan magnit atau gravitasi dan kenyataan-kenyatan lain yang menjadi bahan kajian fisika subatomik dan fisika baru lainnya, yang sampai sekarang masih menjadi bahan kontroversi), sedangkan yang harus dipahami olehmanusia melalui wahyu ialah kenyataankenyataan yang tidak empiris, sehingga tidak ada klemungkinan manusia mengetahuinya kecuali melalui sikap percaya dan menerima (iamn dan islam) atas khabar para nabi. ${ }^{20}$ Dengan demikian, alam menjadi objek pemahaman sekaligus sumber pelajaran.

Dalam upaya memahami alam sekitar itu, manusia mengerahkan dan mencurahkan akalnya. Oleh karena itu alam menjadi obyek pemahaman sekaligus sumber pelajaran hany untuk mereka yang berfikir saja. Bentuk kegiatan memahami alam itu ialah akal (,,aql, tidak sebagai kata benda konkrit, melainkan sebagai kata benda abstrak atau mashdar dari kata kerja aqala ya'qilu yang artinya berfikir, jadi berupa kegiatan memahami atau mempelajari dan mengambil pelajaran. Oleh karena itu, akal bukanlah alat pada manusia untuk menciptakan kebenaran, melainkan untuk memahami atau barangkali menemukan kebenaran yang memang dari semula sudah ada dan berfungsi dalam lingkungan di luar diri manusia.

\section{Ilmu Pengetahuan Mendukung Iman}

Secara aktual manusia memang belum, dan mungkin tidak akan pernah, memahami

\footnotetext{
${ }^{20}$ Nurcholish Madjid, Islam Doktrin dan Peradaban, 292.
} 
seluruh alam raya. Namun secara potensial, manusia dapat memahami alam itu. Ketika terungkap seluruh rahasia alam ini, baik mikro dalam diri manuisia sendiri maupun makro dalam seluruh cakrawala, maka pada saat itulah manusia akan menyadari sepenuhnya kebenaran ilahi.

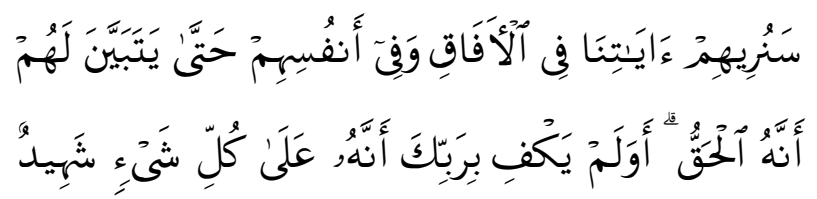

Akan Kami perlihatkan kepada mereka (m anusia) tanda-tanda Kami di seluruh cakrawala dan dalam diri mereka sendiri, sehingga akan menjadi jelas bagi mereka bahwa Al-Qur'an atau bisa juga Tuhan itu benar adanya. QS. Fushshilat (41): 53

Namun manusia, dalam memanfaatkan alam itu harus tidak membatasi diri hanya untuk tujuan mengeksploitasi alam, tetapi ia harus memanfaatkan alam itu sebagai sumber pengambnilan pelajaran dalam mendekati Allah dan dalam membina hubungan yang serasi dan harmonis dengan sesama makhluk. Maka, selain tidak bersikap eksploitatif, manusia harus juga menunjukkan sikap-sikap yang lebih apresiatif terhadap alam lingkungannya. Sebab, meskipun alam ini memang benar berkedudukan lebih rendah daripada manusia, namun hal itu terjadi hanya dalam hirarki kosmis yang bersifat batiniyyah, yang terbebas dari dimensi ruang dan waktu, seluruh alam dan manusia adalah sama-sama makhluk Allah. ${ }^{21}$ Seperti dalam ayat berikut ini:

Tidaklah seekor pun binatang yang melata di bumi, dan tidak pula seekorpun burung yang terbang dengan kedua sayapnya melainkan umat-umat seperti kamu juga.

Penegasan ini terkait dengan berbagai penjelasan tentang alam raya yang selalu bertashbih kepada Allah, demikian juga semua benda-benda tanpa kecuali juga selalu bertashbih kepada Allah Swt.

Seluruh langit yang tujuh dan bumi bertashbih memujinya,dan juga makhluk hidup di dalmnya. Dan tiada sesuatu apapunkecuali bertashbih memuji-Nya,

\footnotetext{
${ }^{21}$ Nurcholish Madjid, Islam Doktrin dan Peradaban.,
} 295. tetapi kamu (manusia) tidak mengerti tashbih mereka.

Oleh karena itu, sekalipun amnusia adalah makhluk tertinggi dan khalifah Allah di bumi, dan sekalipun alam ini dibuat lebih rendah (taskhir) agar dapat digunakan oleh manusia, tetapi hubungan manusia dengan alam sekitarnya harus disertai dengan sikap rendah hati yang sewajarnya, dengan melihat alam sebagai sumber ajaran dan pelajaran untuk menerapkan sikap tunduk kepada Allah (islam). Manusia harus menyertai alam sekitarnya dalam bertashbih memuji Allah, antara lain dengan memelihara keseimbangan alam itu dan menunbuhkannya ke arah yang lebih baik (ishlah), bukan dengan cara melakukan kerusakan dan pengrusakan di muka bumi (fasad fil ardhi) ${ }^{22}$

Dengan demikian, ilmu pengetahuan empiris tidak akan ada artinya, jika tidak menjaga persepsi batin manusia mengenai keadaannya, potensi-potensinya, resiko-resiko yang dihadapinya sebagai manusia, dan nasibnya di akhirat nanti.

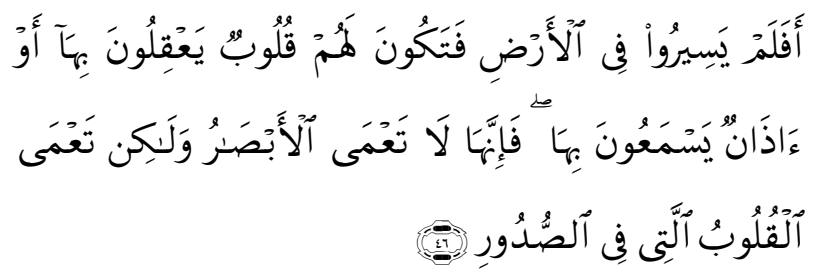

Tidak pernahkah mereka berjalan di atas bumi sehingga mereka memiliki hati untuk memahami dan memiliki telinga untuk mendengar? Karena yang buta bukanlah mata, tetapi hati di dalam hati mereka. (AlHajj/22: 46)

Itulah sebabnya mengapa Al-Qur'an mementingkan tiga macam pengetahuan untuk manusia. Pertama, pengetahuan menganai alam yang telah dibuat oleh Allah tunduk kepada manusia atau sains-sains alamiah. Kedua, pengetahuan sejarah dan geografi. Dalam hal ini, Al-Qur'an senantiasa mendesak manusia agar "berjalan di muka bumi" sehingga dapat menyaksikan apa yang terjadi pada kebudayaankebudayaan di masa lampau dan mengapa kebudayaan-kebudayaan itu bisa bangkit dan runtuh. Ketiga, pengetahuan mengenai dirinya sendiri karena "Kami akan memperlihatkan kepada mereka tanda-tanda

\footnotetext{
22 Nurcholish Madjid, Islam Doktrin dan Peradaban,
} 
Kami di dalam cakrawal dan di dalam diri-diri mereka sendiri sehingga mereka dapat memahami kebenaran - Tidak cukupkah Tuhanmu sebagai saksi tyerhadap sestiap sesuatu? (41:53)

Ilmu pengetahuan ini adalah ilmu pengetahuan ilmiah karena didapatkan dari hasil pengamatan dengan mata dan telinga, tetapi ilmu pengetahuan ini pada akhirnya harus "sampai ke hati" dan mampu menghidupkan iman dan persepsi batin manusia. Tanpa memiliki persepsi batin ini, ilmu pengetahuan dan teknologi itu dapat menjadi kekuatan yang sangat berbahaya. Dengan demikian, pengembangan ilmu pengetahuan, di satu sisi, haruslah dibarengi dengan kekuatan iman dan penajaman persepsi batin di sisi lain.

Dari sini dapat dikatakan bahwa menurut Al-Qur'an, tiga daya yang dapat dipakai untuk memahami kebenaran, yaitu al-fikr, al-,,aql, dan al-fu'ad atau al-qalb merupakan satu kesatuan oragnik yang sifatnya berlapis dan berjenjang. Integrasi ilmu pengetahuan dan teknologi, filsafat, dan agama sangat mungkin karena obyek kajiannya mempunyai kesatuan sumber, yaitu ayat-ayat Tuhan yang ada pada alam semesta, diri manusia dan sejarah, serta yang tersurat dalam kitab suci. Integrasi ketiga tahapan tersebut sebenarnya merupakan wujud integrasi dari perpanjangan ayat-ayat Allah. Integrasi ilmu pengetahuan dan teknologi, filsafat, dan agama meruapakn tuntutan realitas kehidupan itu sendiri di mana ketiganya dapat saling melengkapi. Jika ilmu pengetahuan dan teknologi digunakan untuk memecahkan persoalan-persoaln yang bersifat teknis, operasional, maka filsafat memberikan landasan hakekat dan maknanya terhadap sesuatu hal, memberikan wawasan yang meta teknis dan metafisik, dan selanjutnya agam memberikan arah dan tujuan yang paling akhir dari hidup manusia agar semua proses itu berjalan sebagai bagian dari penghambaannya kepada Tuhan dalam dimensi spiritual.

Inilah maksud dari apa yang dikatakan oleh Kuntowijoyo bahwa ayat Al-Quran hendaknya
Sebagai landasar teori (grand theory) dalam meneliti dan menyelidiki ayat-ayat Tuhan yang tersebar alam, diri manusia dan sejarah. Sebaliknya, maka temuan-temuan inilah yang harus dipakai untuk menjustifikasi kebenaran kalam Tuhan yang tersurat dalam AlQur'an.

Akan Kami perlihatkan ayat-ayat Kami yang terdapat di berbagai ufuq dan dalam diri mereka sendiri sampai menjadi jelas bahwa ayat-ayat yang tersurat dalam AlQur'an adalah benar. Belum cukupkah bahwa Tuhanmu Maha menyaksikan segala sesuatu. (Qs. Hamim As-Sajdah: 53).

Seandainya penelitian ilmiah menggunakan prosedur sebagaimana yang diungkapkan Alquran maka dapat dikatakan ia merupakan seorang yang ulul albab. Yakni, orang-orang yang tidak hanya berdzikir dalam keadaan duduk, berdiri, dan berbaring, tetapi juga mereka berpikir, meneliti, dan merenungkan fenomena alam semesta, diri manusia, dan sejarah. Setelah mereka menemukan kebenaran melalui alam raya, mereka mengatakan, rabbana ma khalaqta hadza bathilan shubhanaka fa qina adzaban nar.

Inilah orientasi keilmuwan Islam yang akan dikembangkan di UIN nantinya. Jika orang Barat mengatakan, science for the sake of science (ilmu untuk ilmu), atau l'art pour l'art, maka kita harus mengatakan science for the search of God, ilmu itu untuk mencari dan menuju Tuhan. Oleh karena itu, Cak Nur menulis buku yang berjudul Pintu-Pintu menuju Tuhan. Jika tidak demikian halnya, maka yang terjadi adalah sebaliknya. Seperti dikatakan oleh Nabi yang bersenjata, Muahmmad Saw., Man yazdad ,ilman lam yazdad hudad, lam yazdad minallahi illa bu'dan. Artinya, siapa yang bertanbah ilmunya, tetapi tidak bertambah petunjukknya. Maka ia akan semakin jauh dari Tuhan.

\footnotetext{
${ }^{24}$ Kuntowijoyo, Paradigma Islam: Interpretasi untuk Aksi (Bandung, Mizan, 1991).
}

\footnotetext{
${ }^{23}$ Fazlur Rahman, Tema Pokok Al-Qur'an, 51.
} 
Dengan menggunakan bahasa agama, seperti dikatakan oleh Prof. Mukti Ali, bahwa ilmu yang dimiliku bukan untuk mengeksploitasi atau pun berkuasa tetapi sejatinya untuk ibadah. Senada dengan perkataan Muhamamd Iqbal, dalam The Reconstruction of Religious Thought in Islam.

Orang mukmin adalah cakrawala hanyut dalam dirinya, sementara orang kafir adalah dirinya hanyut dalam cakrawala.

\section{Iman dan Ilmu Pengetahuan: Sejalan atau Bertentangan?}

Jadi, apakah ilmu pengetahuan dan teknologi itu mendukung atau menentang keimanan kita kepada Allah? Tentu saja, dalam perspektif Al-Qura'an, ilmu pengetahuan itu mendukung keimanan kita kepada Allah Swt. Dengan bukti-bukti berikut ini. Pertama, ketika Al-Qur'an tentang alam raya dan fenomenanya, terlihat secara jelas bahwa pembicaraannya selalu dikaitkan dengan kebesaran dan kekuasaan Allah Swt.

Misalnya, uraian Al-Qur'an tentang kejadian alam:

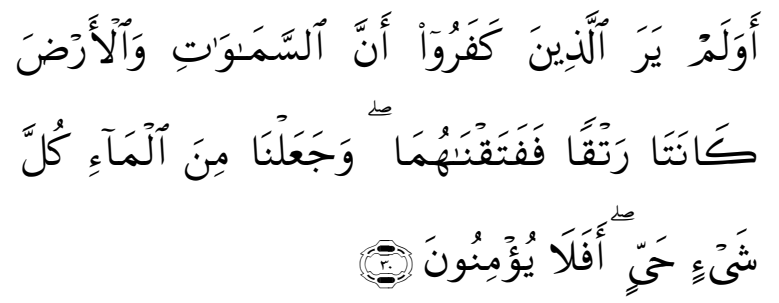

Apakah orang-orang kafir tidak mengetahui bahwa langit dan bumi itu keduanya dahulu adalah satu yang padu, kemudian Allah memisahkan keduanya dan dari air, Kami jadikan segala sesuatu yang hidup. Maka mengapa mereka tidak juga beriman? (Al-Anbiya'/21: 30)

Ayat tersebut dipahami kebanyakan ulama kontemporer sebagai isyarat mengenai teori big bang (ledakan besar) yang mengawali terbentuknya langit dan bumi. Para pakar boleh berselisih pendapat mengenai makna ayat tersebut. Atau mengenai proses terjadinya pemisahan langit dan bumi. Yang pasti, ketika Al-Qur'an berbicara tentang hal itu, dikaitkannya dengan kekuasaan dan kebesaran Allah serta keharusan beriman kepada-Nya.

Pada saat mengisyaratkan pergeseran gunung-gunung dari posisinya, sebagaimana dibuktikan oleh para ilmuwan, informasi itu dikaitkan dengan kemahahebatan Allah Swt.

(Surat an-Naml/ 27: 88).

Kamu melihat gunung-gunung yang kamu mengira tetap di tempatnya, padahal mereka berjalan sebagaimana awan. Begitulah perbuatan Allah, yang membuat dengan kokok tiap-tiap sesuatu. Sesungguhnya, Allah mengetahui apa yang kamu kerjakan.

Ini berarti bahwa ilmu pengetahuan harus selalu mengingatkan manusia akan kehadiran dan kemahakuasaan Allah, selain itu memberikan manfaat secara luas, sesuai dengan prinsip bismi rabbik. ${ }^{25}$

Kedua, Al-Quran sejak awal memperkenalkan istilah sakhkhara yang makna tersebut bermuara terhadap kemampuan meraih secara mudah dengan kemampuan teknik ataupun keahlian. Ketika Al-Quran memilih kata sakhkhara yang artinya secara harfiah menundukkan atau merendahkan. Mempunyai tujuan yaitu agar alam raya dengan segala manfaat yang dapat diraih darinya harus tunduk dan dianggap sebagai sesuatu yang posisinya berada di bawah manusia. Bukankah manusia diciptakan sebagai khalifah? Tidaklah etis seorang khalifah tunduk dan merendahkan diri terhadap sesuatu yang telah ditundukkan oleh Allah untuknya. Apabila khalifah ditundukkan oleh alam, maka ketundukan itu tidak sejalan dengan maksud Allah Swt.

Sebagaimana telah dikemukakan di atas bahwa penundukan Allah terhadap alam raya bersama potensi yang dimiliki manusia bila digunakan secara maksimal, akan menghasilkan teknologi.

Dari kedua catatan di atas dapat disimpulkan bahwa ilmu pengetahuan dan teknologi serta hasil-hasilnya disamping harus mengingatkan manusia kepada Allah, juga perlu mengingatkan bahwa manusia merupakan khaliafah yang mengatur alam raya ini.

Jika alat atau mesin dijadikan sebagai gambaran konkrit teknologi, dapat dikatakan

\footnotetext{
${ }^{25}$ Quraish Shihab, Wawasan Al-Quran, 444-445.
} 
bahwa pada mulanya, teknologi merupakan perpanjangan organ manusia. Ketika manusia menciptakan pisau sebagai alat pemotong, alat ini menjadi perpanjangan tangannya. Alat tersebut disesuaikan dengan kebutuhan dan oragan manusia. Alat itu sepenuhnya tunduk kepada si pemakai, melebihi tunduknya budak belian.

Selanjutnya teknologi berkembang pesat, dengan memadukan sekian banyak alat menjadi satu mesin. Seperti: Kereta, mesin giling, dan sebaginya semuanya berkembang. Energi yang digunakan sebelumnya seperti energi manusia atau binatang, diganti dengan energi air, uap, api, angin, dan sebagainya. Pesawat udara, misalnya, adalah mesin. Kini, pesawat udara tidak lagi menjadi perpanjangan organ manusia, tetapi perluasan atau penciptaan organ baru manusia. Bukankah manusia tidak memiliki sayap yang memungkinkannya untuk terbang? Tetapi dengan pesawat, ia bagaikan meiliki sayap. Alat atau mesin tidak lagi menjadi budak, tetapi telah menjadi kawan manusia.

Dari hari ke hari, telah tercipta mesin-mesin yang semakin canggih. Mesin-mesin itu melalui daya akal manusia digabungkan dengan yang lainnya, sehingga semakin kompleks serta tidak bisa dikendalikan oleh seseorang. Maka akhirnya, mesin yang diciptakan manusia dapat mengerjakan tugas dilakukan oleh banyak orang. Pada tahap ini, mesin menjadi semacam musuh manusia, atau lawan yang harus disiasati agar mengikuti kehendak manusia.

Era kontemporer ini telah lahir teknologi,di bidang rekayasa genetika yang ditakutkan dapat menjadikan alat sebagai majikan. Yang mampu menciptakan bakal-bakal majikan yang diperbudak dan ditundukkan oleh alat. apabila begitu, tentu jelas bertentangan dengan kedua catatan yang disebutkan terdahulu.

Berdasarkan petunjuk kitab suci, seorang muslim dapat menerima hasil-hasil teknologi yang sumbernya netral, dan tidak menyebabkan kemaksiatan, apabila bermanfaat bagi manusia, ditinjau dari unsur "debu, tanah" manusia maupun unsur "ruh ilahi" manusia.
Apabila aplikasi dari hasil teknologi membuat manusia lalai dari dzikir dan tafakkur, serta meruntuhkan nilai-nilai kemanusiaan, maka bukan hasil teknologinya yang harus ditolak, melainkan mestinya kita memperingatkan dan mengarahkan manusia terhadap penggunaan teknologi itu. seandainya hasil teknologi sejak awal dapat mengalihkan manusia dari jati dirinya dan tujuan penciptaannya, maka kehadirannya dari awal harus ditolak oleh Islam. Karena itu, menjadi persoalan besar bagi martabat manusia dalam memadukan kemampuan mekanik dalam penciptaan teknologi, dengan memelihara nilai-nilai fitrah manusia dengan memadukan pikir dan dzikir, ilmu dan iman. 27

Dengan demikian, Ilmu Pengetahuan sudah semestinya berjalan seiring dan sejalan dengan keimanan seorang manusia kepada Tuhannya. Keseimbangan antara keduanya, yakni memiliki ilmu yang tinggi dan iman yang kuat adalah syarat agar seseorang dapat diangkat oleh Allah Swt. Kepada derajat yang lebih tinggi, baik derajat di dunia maupun derajat di akhirat. Sebagaimana disebutkan dalam AlQur'an berikut ini:

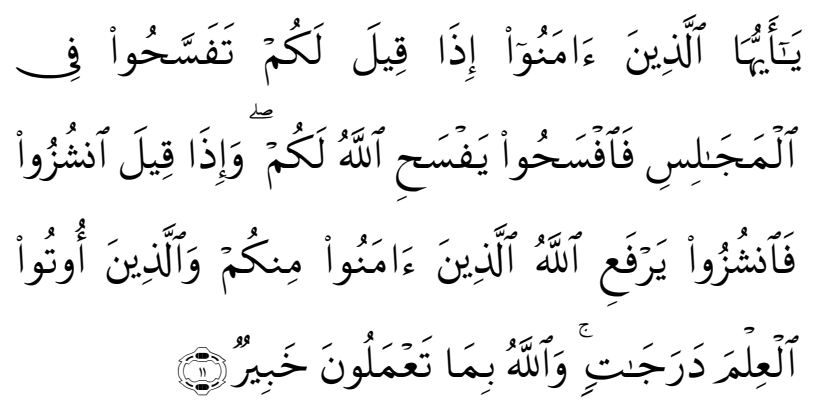

Allah akan mengangkat orang-orang beriman di antara kamu dan orang-orang yang telah diberi ilmu beberapa derajat. Dan Allah Maha Tahu atas apa yang kamu perbuat. (QS. Al-Mujadalah: 11)

Menurut Ibnu Abi Hatim dari Muqatil bahwa ayat ini diturunkan pada hari Jum'at dimana orang-orang yang termasuk ahli Badr telah datang, sementara tempatnya sempit dan belum diperluas untuk mereka. Oleh karena itu, mereka berdiri karena tidak ada tempat

\footnotetext{
${ }^{27}$ Quraish Shihab, Wawasan Al-Quran,446.
}

\footnotetext{
${ }^{26}$ Quraish Shihab, Wawasan Al-Quran., 445-446.
} 
untuk duduk. Melihat hal itu, Nabi Saw. menyuruh seseorang untuk berdiri agar tempatnya bisa diduduki oleh yang lain, tetapi orang itu merasa tidak suka. Maka turunlah ayat ini.

Ayat ini menunjukkan bahwa iman dan ilmu pengetahuan tidak bertentangan dan sudah seharusnya berjalan seiring karena Allah Swt. mengangkat derajat manusia itu berdasarkan dua hal: iman yang kuat dan ilmu pengetahuan yang tinggi. Hanya saja, dalam ayat ini, iman lebih didahulukan dari pada ilmu. Dengan demikian, dapat diambil kesimpulan bahwa iman itu lebih penting daripada ilmu pengetahun. Sementara ilmu pengetahuan itu sebagai penunjang untuk menyirami dan menumbuh-kembangkan iman yang ada di dalam diri manusia. Jadi, tidak ada pertentangan antara iman dan ilmu pengetahuan. Ilmu pengetahuan yang dimiliki oleh manusia adalah sarana untuk menemukan kebenaran Al-Quran dan kebenaran Tuhan itu sendiri.

Menurut Nurcholish Madjid, ayat ini dapat dimaknai bahwa janji keunggulan, superioritas dan supremasi diberikan oleh Allah kepada mereka yang beriman dan berilmu sekaligus. Iman akan mendorong manusia untuk berbuat baik untuk mendapatkan ridha Allah, dan ilmu akan melengkapi manusia dengan kemampuan menemukan cara yang paling efektif dan tepat dalam pelaksanaan dorongan untuk berbuat baik itu. Dengan kata lain, iman mendidik kita untuk memiliki komitmen kepada nilai-nilai luhur dan ilmu memberi kita kecakapan teknis guna merealisasikannya. Singkatnya, iman dan ilmu pengetahuan secara bersama akan membuat manusia menjadi orang baik dan sekaligus tahu cara yang tepat mewujudkan kebaikan itu. Maka dapat dimengerti mengapa iman dan ilmu merupakan jaminan keunggulan dan superioritas. 29

Memang secara hirarki nilai, masih tetap dapat dikenali bahwa iman adalah primer,

\footnotetext{
${ }^{28}$ Jalaluddin al-Suyuthi, Lubāb al-Nuqūl fì Asbāa alNuzūl, (Libanon: Dar al-Kutub al-,Ilmiyyah, 2012), 186.

${ }^{29}$ Nurcholish Madjid, Pintu-Pintu Menuju Tuhan, cet. iii (Jakarta: Paramadina, 1995), 8.
}

yang utama, dan ilmu adalah sekunder, pelengkap. Ini dapat dilukiskan: "lebih baik seorang yang jujur, meskipun bodoh daripada seorang yang jahat meskipun berilmu." Atau, "lebih baik orang yang bodoh tapi jujur, daripada orang pandai tapi jahat." Sebab kepandaian di tangan orang jahat akan menunjang kejahatannya itu sehingga berlipat ganda dan semakin merusak, seperti terbukti dari kejahatan kaum Nazi Jerman.

Namun, jika masalahnya ialah keberhasilan usaha kebaikan yang maksimal, maka sesungguhnya iman dan ilmu pengetahuan itu tidak dapat dipisahkan. Kekalahan orang atau kelompok yang baik oleh orang atau kelompok yang jahat jelas bukan karena faktor iman orang atau kelompok yang baik itu, tetapi hanya karena faktor ilmunya yang kurang itu. Salah satu wujud nyata peran ilmu adalah, misalnya, kemampuan berorganisasi dan menyusun kiprah. Oleh karena itu, terkenal sekali diktum, "al-bathil bi nizham yaghlibu al-haqq bi ghayr nizham." Kepalsuan yang tersusun rapi akan mengalahkan kebenaran yang tidak tersusun rapi. Sesuatu hal yang amat logis dan masuk akal.

Masalah yang cukup pelik ialah, jika seseorang mempunyai iman, namun tidak berilmu secukupnya, maka ada kemungkinan, ia akan melaksanakan suatu itikad baik secara kurang tepat atau tidak jarang terjadi, melaksanakannya begitu rupa sehingga hasilnya justru hal yang tidak dikehendaki dan berlawanan dengan itikad baiknya sendiri. ${ }^{3}$

Dengan iman dan ilmu pengetahuan, manusia akan memperoleh derajat ketaqwaan. Taqwa adalah istilah terpenting dalam AlQur'an. Taqwa pada tingkat yang tinggi menunjukkan kepribadian manusia yang benar-benar utuh dan integral. Kata taqwa biasanya diartikan sebagai "takut kepada Allah" atau "keshalehan". Jika taqwa dimaknai sebagai takut kepada Allah, maka hal itu mengesankan

\footnotetext{
${ }^{30}$ Nurcholish Madjid, Pintu-Pintu Menuju Tuhan., $8-9$.

${ }^{31}$ Nurcholish Madjid, Pintu-Pintu Menuju Tuhan., 9.
} 
bahwa Allah adalah sebuah kekuatan yang diktator dan kejam karena rasa takut kepada Allah tidak dapat dibedakan dengan rasa takut kepada srigala.

Taqwa berasal dari kata waqaya, yang berarti berjaga-jaga atau melindungi diri dari sesuatu. Kata taqwa dengan makna ini digunakan juga dalam Al-Qur'an, seperti dalam Surat 52: 27; 40: 45; 76: 11. Jadi, takwa berarti melindungi diri dari akibat-akibat perbuatan diri sendiri yang buruk dan jahat. Dengan demikian, istilah takut kepada Allah dengan pengertian takut kepada akibat-akibat perbuatan diri sendiri, baik akibat di dunia maupun di akhirat, adalah tepat sekali. Dengan kata lain, inilah perasaan takut yang timbul karena kita sadar bahwa kita memiliki tanggung jawab dunia akhirat. Rasa takut ini tidak sama dengan rasa takut kepada srigala atau kepada seorang raja yang lalim, kejam, dan semena-mena karena Tuhan dalam Al-Qur'an adalah Tuhan yang Maha Pengasih dan Penyayang, walaupun Dia juga menjatuhkan hukuman-Nya di dunia dan di akhirat nanti. ${ }^{32}$

\section{E. SIMPULAN}

Dari berbagai ayat Al-Quran, dan penjelasan para penafsir Al-Quran seperti Fazlur Rahman, Quraish Shihah, dan Nurcholish Madjid dapat diperoleh beberapa kesimpulan di bawah ini:

1. Ilmu pengetahuan yang dimiliki manusia adalah sarana untuk menemukan kebenaran Al-Quran dan kebenaran Tuhan itu sendiri. Ilmu pengetahuan dalam perspektif AlQur'an diberikan kepada manusia sebagai bekal manusia menjadi khalifah di muka bumi. Oleh karena itu, ilmu pengetahuan manusia tidak dapt dipiosahkan dari keiumannnya. Dengan ilmu pengetahuan dan iman yang dimilikinya, Allah akan mengangkat derajat manusia, tdaik hanya di dunia, tetapi juga di akhirat. Dengan demikian, segala hal yang terkait dengan pengembangan ilmu pengetahuan dan teknologi harus diupayakan dalam rangak memperkuat keimanan kepada Allah dan

\footnotetext{
${ }^{32}$ Fazlur Rahman, Tema Pokok Al-Qur'an, 43.
}

semakin mendekatkan diri manusia kepada Allah Swt.

2. Pertentangan yang terjadi antara ilmu pengetahuan dan teknologi, bukan disebabkan oleh oleh ajaran Al-Quran, tetapi karena manusia memiliki beberapa kelemahan: a. Memiliki hawa nafsu yang mendorong amnusia selalu konflik kepentingan dengan sesamanya $b$. Kesempitan pikiran, yakni manusia lebih emmentingkan kepentingan jangak pendek dari pada kepentingan jangka panjang.

\section{DAFTAR PUSTAKA}

Abu Zaid, Nasr Hamid. Tekstualitas AlQur'an: Kritik terhadap Ulumul Qur'an. Yogyakarta: LKiS, 2001.

Anshari, Endang Saifuddin. Ilmu Filsafat dan Agama. Surabaya: PT Bina Ilmu, 1990.

Farmawi, Abd al-Hayy. Metode Tafsir Mawdhu'iy: Suatu Pengantar, terj. Suryan A. Jamrah, cet. ii. Jakarta: PT Rajagrafindo Persada, 1996.

Faudah, Mahmud Basuni. Tafsir-Tafsir AlQur'an: Perkenalan dengan Metodologi Tafsir, cet. i. Bandung: Penerbit Pustaka, 1987.

Furchan, Arief. Peranan Agama dalam Pembangunan Iptek Nasional 1. Diunduh pada tanggal 24 Januari 2013 dari http://www.pendidikan islam.net/index.php/makalah/41-makalahtertulis/272-peranan-agama-dalampembangunan-iptek

Ibnu Katsir, Isma'il. Tafsīr al-Qur'ān al„Azhìm. Damaskus: Maktabah Dar alFiha', 1998.

Khallaf, Abdul Wahhab. „Ilmu Ushul al-Fiqh. Tk.: Dar al-Rasyid, 2008.

Kuntowijoyo, Paradigma Islam: Interpretasi untuk Aksi. Bandung, Mizan, 1991.

Madjid, Nurcholish. Islam Doktrin dan Peradaban: Sebuah Telaah Kritis tentang Masalah Keimanan, Kemanusiaan, dan Kemoderenan, cet. Ii. Jakarta: Paramadina, 1992.

Pintu-Pintu Menuju Tuhan, cet. iii. Jakarta: Paramadina, 1995. 
Maran, Rafael Raga. "Agama Iptek dan Masa Depan Kita", dalam Buletin Ilmiah Tarumanagara Th. 9/ No. 31 (1994); 7177.

Maqdisi, Hasani. Faydhullah. Fath al-Rahman li Thalibi Ayatil Qur'an. Indonesia: Maktabah Dahla, Tanpa tahun.

Rahman, Fazlur. Tema Pokok Al-Qur'an, terj. Anas Mahyuddin, cet. i. Bandung: Penerbit Pustaka, 1983. Islam dan Tantangan Modernitas tentang Transformasi Intelektual. Bandung: Penerbit Pustaka, 1995.

Razi, Fakhruddin. Tafsīr Mafätih al-Ghayb. Tehran: Dar al-Kutub al-,Ilmiyyah, Tanpa tahun.
Shah, A.B. Metodologi Ilmu Pengetahuan. Jakarta: Yayasan Obor Indonesia, 1986.

Shihab, Quraish. "Membumikan" Al-Qur'an: Fungsi dan Peran Wahyu dalam Kehidupan Masyarakat, cet. i. Bandung, Mizan, 1992.

\section{Wawasan Al-Qur'an: Tafsir} Maudhu'i atas Pelbagai Persoalan Umat, cet. iv. Bandung, Mizan. 1996.Suyuthi, Jalaluddin. Lubāb al-Nuqūl fì Asbāb alNuzūl. Libanon: Dar al-Kutub al„Ilmiyyah, 2012.

Whittingham, Martin. "Muslim Methods of Qur'an Interpretation", in Whitefield Briefing Vol 8. No. 3. (August 2003). 
